\title{
Dynamics of Moslem Scholars in Jakarta: the Role of Ahmad Zayadi in Klender East Jakarta
}

\author{
Abd. Wahid Hasyim \\ Department of Islamic History and Civilization \\ Faculty of Adab and Humanities \\ Syarif Hidayatullah State Islamic University (UIN) Jakarta \\ Indonesia \\ abd.wahid@uinjkt.ac.id
}

\begin{abstract}
This study investigates the role of Ahmad Zayadi in developing religious social transformation in Klender East Jakarta. Based on the 2003 census, the population of Klender was 57,648 people and most of them are Muslim. However, their religious understanding was still relatively weak, and the level of education was left far behind compared to other areas in Jakarta. These conditions encouraged Zayadi, a charismatic scholar, Betawi-Banten descent, to preach through recitations in mosques and the modest mosque inherited by his great-grandfather. Even prior to his demise, he built Islamic educational institutions and other formal educational institutions in a classical manner, including elementary schools, senior high schools and colleges. The Islamic educational institutions and other formal educational institutions still exist until now and many of its alumni take part in the modern and global society. This research uses Qualitative analysis with a historical and social approach to analyze the data. The findings indicated that during his life from 1933 to 1994 Zayadi had been involved in religious, educational, and social movements that make him to be considered one of the three of the most respected Islamic scholars in Jakarta.
\end{abstract}

Keywords—role; Ahmad Zayadi; religious social; transformation; Islamic scholars in Jakarta

\section{INTRODUCTION}

Geographically, Klender is a small, quiet and sparsely populated area whose administration is part of Duren Sawit sub district, East Jakarta municipality. Based on a census in 2003, Klender encompasses an area of 304.90 hectare with the number of population of 57.648 people. The majority of the people are Muslims but in terms of religious understanding it is relatively weak, even in terms of education it is left behind compared to other parts of Jakarta. This condition spurred Abuya, the nickname for Ahmad Zayadi (Herein after written with this term), a charismatic religious scholar of BetawiBanten decadence to preach through recitations in mushallamushalla (a smaller place than the mosque for Muslim to pray) and a simple mosque built by his ancestors. Even before he passed away, He built an Islamic boarding school (pesantren) and formal educational institution from elementary to high school and university. The Pesantren and educational institutions still exist hitherto. Many of the graduates are active in many Islamic activities such as teaching religion, preaching, holding education institutions and many others. Religious activities being initiated and propagated by Zayadi has resulted in the improvement of society in terms of understanding their religious teachings. Therefore, as a token of appreciation, the society or people around Klender respect Abuya highly and Abuya even becomes more popular and one of the three highly respected Islamic scholars not only in Klender but also in Jakarta. Other two scholars of the three-worth mentioning are Hasbiyallah and Mursyidi. The appreciation from Islamic society around Klender in particular and Jakarta in general to Zayadi can also be observed in the time of Zayadi's death and burial in the West part of al-Husna mosque, in the area of az-Ziyadah institution. Many mourners both from officials state and community leaders, such as Habib Ali Abdurrahman asSegaf, Habib Abdurrahman as-Segaf, Idham Khalid, Syafi'i Hadzami, Syibro Malisi,Suryadi Sudirdja, State minister and the chairman of National soil were present to honor him. etc. [1].

\section{METHOD}

This research uses qualitative method with historical and social approaches. Thus, the data collection is obtained through interview, observation, documentation research and study on the texts. Data is emphasized more on the qualitative not the quantitative one. S.P Varma said that a research based on an individual or the prominent figure needs to see the individual's position and the role that figure performed within the society. If each individual has a different role in different context then this can be explained by looking at the diversity of different behaviors [2]. So, a triangulation method to compare the result of interview is necessary. Whereas, the data analysis technique is simultaneously conducted with the data collection itself. Subsequently, the data obtained then are classified, filtered, and generalized. Then the theoretical constructions are made. Through this process, the researcher tries to understand, to 
arrange the categories, and to make an inventory the characteristics of each category.

\section{RESULT AND DISCUSSION}

Klender is a name of a village in East Jakarta which is not popular in DKI Jakarta, because besides it is a small village which is administratively part of Duren Sawit urban village. The term kampong is usually associated with the name of ethnic groups in archipelago who came to Jakarta as immigrants but eventually stayed in DKI Jakarta. The name of the kampong is then named after the origin of the people who settled there such as Kampong Melayu, Kampong Bali, Kampong Bugis, Kampong Makassar, Kampong Ambon and Kampong Jawa [3], [4].

Klender and its surrounding area was a quiet and sparsely populated place. On the sides of the path lies paddy fields, rubber forest, bushes and the houses were far apart from one another. In the Dutch colonial period in 1935, Klender was part of Jatinegara, based on the master plan of the Dutch colonial government which divided Batavia into different parts like the city in the Netherlands but in the other parts there were still remained indigenous settlements. In the Japanese occupation, based on the Law of Centralization of 8 August 1942, Jakarta was designated as the Extraordinary Stand Gemente or Batavia Tokubetsu Si, which placed Klender sub district, Desa Jatinegara, Cipinang Pondok Bambu sub district, Pulogadung sub district, Cakung sub district became part of Pulogadung sub district. After the independence of the Republic of Indonesia on 17 August 1945 during the rule of National government of the City of Djakarta, Klender became part of Kawedanan Matraman, Pulogadung subdistrict. At that time, The National government of the City of Djakarta divided the names of Desa, Subdistrict (Kecamatan) and Kawedanan (a term in the past for a subdistrict within a regency) into Djakarta Municipiality based on the regulation issued by BPUP Kotapradja of Djakarta dated 13 February 1956 which stated that each sub district was divided into Urban villages with 6 Kawedanan (formerly subdistrict), 20 Subdistrict (kecamatan) (Onderdistrik) and 136 Urban villages (Kelurahan).

Thus, Klender was a strategic region because it is located in the Northern part of Duren Sawit subdistrict, East Jakarta. In terms of social economy, Klender has a fairly dense population. The number of population in Klender in 2003 was +57.648 people, consisting of Betawise, Javanese, Arabic, Sundanese, Chinese and Madurese. The migrants who came to Klender in 2000, especially in East Jakarta were mostly engaged in the informal sector such as street vendors, manual laborers, caseworkers, construction workers, scavengers, food and home industry beverage sellers, retailer, cigarette sellers and the like. They entered this sector, because it is something that is easily accessible without any requirements of an educational certificate and skill. While the natives of Klender (Betawinese) work as trade workers with their prominent characteristic of gotong royong applied in the neighborhood cleanup, national events and religious events.

Viewed from religion, the Klender population which reached 57,684 people, embrace various religions and beliefs with Muslims as the majority, whereas, there are very few nonMuslims. This is due to the pattern of development and fostering of Islam by the ulama which is felt to be very beneficial by the community. One of the leading Betawi scholars who played an important role in fostering Muslim society in Klender was Ahmad Marzuki (1876-1934). He founded a School (Pesantren) in Muara Village, Cipinang Lontar, East Jakarta. There are quite a lot of students or santri, reaching up to 50 people. Among his famous students are Abdul Jalil of Tambun, Mukhtar Tabrani of Kali Abang Bekasi, Ahmad Mursyidi and Ahmad Zayadi. Besides Ahmad Marzuki, Muhammad Sholeh bin Tinggal, known as Mu'allim Ale (Amad teacher), a Banten scholar who moved and settled in Kampung Tanah 80 Klender East Jakarta, also played a significant role in shaping and building Muslim society around Klender. He founded the Pesantren ir Islamic boarding school and at the first time the number of thesantri or pupil was approximately 15 people. However, when Muhammad Sholeh's health deteriorated, Zayadi then was asked to continue the struggle to educate the 15 students he left behind, in the field of religion, through his teachings held in a simple mosque. In addition to that Zayadi also held a study in 58 mushollas (a smaller place of prayer than the mosque for Muslim) and 12 mosques around his residence.

Thus, through the role of both ulama and continued by their students, it can be said that from the beginning of the 20th century various educational facilities such as education on how to read the Qur'an for children in homes, langgar-langgar (a smaller place of prayer than the mosque for Muslim) and pesantren have been established. After that classical educational institutions were also built ranging from the level of Ibtidayah, Tsanawiyah, Aliyah (Junior and Senior High School) and Colleges. The development of these educational institutions cannot be separated by the role played by the strategic elite of Klender, so it is natural that among these educational institutions, some has historical background of the struggle against the hegemony of the Dutch colonizers such as the Foundation of al-Fatah, al-Wathoniyah and al-Ziyadah. Through the role of these two institutions in education, that Islam become the most dominant religion being adhered by the majority of the Klender community. Based on the latest data, the number of Muslims of Klender community was 52,568 people, almost reaching $92.09 \%$ of the whole population with the number of mosques reaching 12 units and 58 mushollas. (a smaller place of prayer than the mosque for Muslim) Based on the above explanation, it can be ascertained that in terms of 'ubudiyah, (worship) the majority of Klender community adheres to the Shafi'i school, due to the role of Ahmad Marzuki, who founded the pesantren. Most of the students came from Klender and when they returned to their village, they taught the knowledge they got from the pesantren, so that the Klender society is now assembled in Ahlussunnah wa al- Jama'ah and $\mathrm{NU}$ as its religious social organization [5].

One of the characteristics of Ahlussunnah wa alJama'ah or Sunnite group is to highly respect the views of previous scholars, and Nahdlatul Ulama, as a religious social 
organization also adheres to the Qur'an and Hadith as a source of Islamic teachings while in figh adheres to one school, the Shafi'i school; in the field of Tawheed embrace the teachings of Imam Abu Hasan al-Ash'ari and Imam Abu Mansur alMaturidi, while in the field of tasawuf adheres to the foundations of Imam Qasim al-Junaid [6].

The next issue is what role Ahmad Zayadi did in developing of Religious Social Transformation? Zayadi gave more emphasis on performing Da'wah bi al-Lisan and bi al-Hal (Preaching by giving a speech and teaching and preaching by giving good examples). Da'wah bi al-Lisan was conducted in the form of teaching with the help of his parents and was followed by conducting halaqah recitation along with two other great scholars, namely Hasbiyallah and Ahmad Mursyidi. The materials being taught are related to the problems of Fiqh (Islamic Jurisprudence), Akhlaq (Islamic Moral) and Tasauf (Islamic Sufism), with the emphasis on worship and ethics as well as noble character. As for dakwah bi al-Hal (Preaching by giving good examples), it is done by giving good examples in the implementation of moral both in words and actions.

In terms of action, he respected and appreciated whoever he knew and came to him. Murodi, a director of the Salaf Pesantren, said "there was a citizen of Chinese descent, whose religion is different but paid a great respect for Zayadi. This Chinese commented on the character of Zayadi that Zayadi was a very good cleric, and had a good moral and character that could be exemplified. Murodi further stated that Zayadi was a scholar who used to carry out the cleaning of his neighborhood surrounding together with his students by sweeping the field, cleaning the mosque. An interesting character of Zayadi is that he never considers the background of people who came to him. Thus, he welcomes all with pleasure [7].

In fulfilling invitations,Zayadi also did not discriminate the rich from the poor. Those living in big houses or those living in rented house, prominent or ordinary people. He tried to attend all the invitations. According to Murodi, Zayadi is a cleric who made many people in Klender, Pondok Kelapa and West Bekasi adhere Islam with great consciousness. Especially in the last region, if there were community celebrations in Bekasi which are used to conduct activities with immoral nuance of immorality, animism and or other bad activities such as gambling and chicken fight, then with good praise, Zayadi asked and invited the community to abandon the disgraceful acts. They followed his advice although it is difficult to prove the standard of measurement [7]. Based on historical data, Zayadi was a cleric who played a role in eliminating gambling, opposed the SDSB (kind of gambling) other types of acts of Munkar (wicked act). Everything is delivered with a wise speech [1].

The role of Zayadi in education, started at the age of fifteen. Due to deteriorating health, his great- grandfather, Muhammad Sholah asked him to continue his struggle to educate the 15 students he left behind. They were educated and nurtured in a study held at a simple mosque. In addition, Abuya also educated and cultivated the community through the study held in 58 mushollas and 12 mosques around Klender [8].
The method of sorogan, bandongan and wetonan, a common method of learning which are commonly used in pesantren throughout Indonesia. However, the most commonly used is halaqah, where santri made a circle then made a long line, while two other santri (student) sit behind Zayadi, while preparing to study and read the book. Zayadi walked around while pulling the grass, cleaning the dirty sewers and cleaning the stones scattered around the pesantren, while the students followed what Abuya did, cleaned up, and tidied up what needs to be tidied up. So, it goes on and on. Furthermore, based on the encouragements of his teachers, Muhammad Thohir, Cipinang Muara and R. Mustaqiem, Rawabening, Jatinegara, Zayadi established Pesantren az- Ziyadah in 1943. The purpose of the establishment of pesantren is to preserve and spread the teachings of Prophet Muhammad SAW and the teachings of Ahlu al-Sunnah wa al-Jama'ah (the sunni) and anticipating the influences of Western culture to Muslim society which are not in line with Islamic values.

Initially Pondok Pesantren az-Ziyadah only consisted of a simple mosque inherited by Muhammad Sholeh, then Zayadi together with the surrounding community through mutual cooperation and self-reliance built a place of study and boarding house. In 1948, he built the student dormitory in its permanent form [9]. The building within the pesantren area, including the mosque which was designed by Zayadi himself and he also took care of the management of Pondok Pesantren az-Ziyadah [4]. In 1949, after performing the pilgrimage with his wife, $\mathrm{Hj}$. Asmanih and seven of his family members, Zayadi continued the task of educating the students who he had left behind during his pilgrimmage.

In 1970, Zayadi built a building for madrasah and dormitory for the students with permanent and multi-storey building. Then in 1972, in line with the issuance of government regulations on religious education, Zayadi combined the traditional education system in the form of recitation of yellow book with the school system with general subjects. According to Zayadi, the modern system of education is not only in the form of the availability of classes to study and the equipment, while the traditional system of education lies not only in the use of sarongs and listening to teachers reading the book, but the modernity of the education system lies in improving what are lacking in the process of teaching and learning to get the best results. "Al-Muhafadhatu al-Qadim al-Shalih wa al-Akhdzu alJadid al-Ashlah (Preserving the good old things and taking the better new ones.) the slogan commonly used by Pesantren in Java and Madura and among Nahdliyyin" [10]. Quoting Mukti Ali, Minister of Religious Affairs of the New Order era, Siti Fatimah asserted that traditional education is bad in teaching, but good in education, while modern education is bad in education, but good in teaching [11]. Thus, according to A. Malik Fadjar, it is necessary to seek the effort towards the creation of a synthesis, convergence or synergy, so that the unity can be achieved [12].

Referring to the above reality, Zayadi established formal educational institutions namely Madrasah Ibtidaiyah, Tsawawiyah and Aliyah. The local curriculum was initially used by the Ministry of Religious Affairs of the Republic of 
Indonesia. To improve the quality of education in Madrasah Aliyah, Madrasah Aliyah az-Ziyadah made improvements to the curriculum by emphasizing on the basis of basic competence, increasing faith and piety (imtak) and science and technology. Such a curriculum was later known as KTSP. According to Yayah Fahriyah, the development of KTSP refers to the National Education Standards to ensure the achievement of national education objectives, which comprise of content standards, processes, graduate competencies, education personnel, facilities and infrastructure, management, financing and educational assessments. SI and SKL are the main reference for the educational unit in curriculum development [13].

Thus, a Madrasah Aliyah az-Ziyadah teacher needs to understand the various new paradigms contained in it that is about the basic framework of KTSP, the purpose of school implementation and the competency of the graduate competency, the program structure, the implementation of the KTSP related to organizing and learning and evaluation or assessment. Besides that, in the curriculum perspective, Madrasah Aliyah az-Ziyadah management is expected to be able to keep up with the development of curriculum that leads to educational innovatively, with the use of Life Skill and Broad-Based Education by positioning the role of education in schools is expected to answer the problems that need to be solved, especially those related to the education component of raw input, process, instrument, environment up to the output [13].

In the curriculum concept, Madrasah Aliyah az-Ziyadah has developed several approaches that teachers need to understand in the field as a thorough implementer, and so as not to misinterpret concepts related to life skills that include personal, social, academic and vocational skills which leads to general life skills and specific life skills. The purpose of developing KTSP in Madrasah Aliyah az-Ziyadah is to improve the quality of learners to be able to master the educational materials in accordance with the teaching field [13]. The vision of Madrasah az-Ziyadah is to establish a first-rate Madrasah which is superior in its achievements based on faith and taqwa. On a vast land and yard, there was built a 3300 sq. building that serves as a classroom, a laboratory of chemistry, physics and biology, a computer lab room, a library room, a multipurpose room, a cooperative room, a principal's room, a teacher's room, TU room, OSIS room, worship room and school guard room and so on, the management strives to realize that vision within cooperation with various state and private universities, such as in PMDK, Seminar, Discussion on Campus, National Examination Try Out, Public Community Service or PPL and Extra Curricular Tutorials. The Alumni, besides becoming entrepreneurs, some become government or private employees, some even continue their studies to State or Private Universities, including STAI Az-Ziyadah.

In 1990, Abuya established a college named Sekolah Tinggi Agama Islam Az-Ziyadah. STAI Az-Ziyadah since its establishment until 2011, has graduated many alumni in two disciplines, Shariah and Islamic Religious Education. They generally work as judges or teachers both in public and private institutions, kiyai (local religious leader), self-employed and others. Therefore, Zayadi's social activities were more focused on fulfilling the needs of the people by building mosques, preaching and holding Quran recitation in 58 musholla and 12 mosques around Klender and building pesantren, madrasah Ibtidaiyah, Tsanawiyah, Aliyah and Higher Education and others. Besides that, Abuya was also active as an imam, preacher, lecturer, educator and manager of the institution he built, became member of the Board of NU Branch of Jakarta from 1980-1994, the MUI board of DKI in the improvement of Islamic education and da'wah. But behind that, Abuya also had the expertise in the field of tasauf and fiqh which can make a community organization as big as NU and a city as big as Jakarta be proud of. There is no kiyai in NU Branch Jakarta that can match the understanding, depth and expertise in the midst of today's dynamic and modern society. His expertise and his work in da'wah, education and social, it is only natural that Zayadi had many relations, ranging from the upper / political elite and lower / common people. Abuya also has many students, including Kiyai, (local religious leader) Ustad (religious teacher), and also founder of LSM and calligraphy art that adorn the mosques in Jakarta [5].

\section{CONCLUSION}

From the above discussion, it can be concluded that Zayadi had a significant role in Developing Religious Social Transformation as it can be observed in the establishment of mushalla, mosque, madrasah and college. It is through his institution, Zayadi became a da'i, imam, preacher, teacher of Qur'an, manager and da'i bi al-Lisan and bi al-Hal. Zayadi was also listed as a member of the board of NU Branch of Jakarta and member of the Board of MUI of DKI Jakarta; His involvement in these activities led Zayadi to be known as a respected scholar and religious leader. His name is known in DKI Jakarta, so Zayadi can be included as the three greatest ulama and kiyai in Jakarta with. Hasbiyallah and Ahmad Mursyidi.

\section{REFERENCES}

[1] A. Fadli, Ulama Betawi, Studi tentang Jaringan Ulama Betawi dan Kontribusinya Terhadap Perkembangan Agama Islam Abad Ke-19 dan 20, Jakarta: Manhalun Nasyi'in, 2011, 184 - 185.

[2] S.P. Varma, Teori Politik Modern, Jakarta: Rajawali Press, 1982.

[3] Hendrowinoto, N. Ki S. et.all., Seni Budaya Betawi Menggiring Zaman, Jakarta: Dinas Kebudayaan DKI Jakarta, 1998.

[4] R. Saidi, Profil Orang Betawi, Asal Muasal, Kebudayaan dan Adat Istiadatnya, Jakarta: Gunara Kata. 2004.

[5] Musthofa, Alumni dan Guru pada Ponpes az-Ziyadah, Wawancara Pribadi, Klender 11 Oktober 2011.

[6], KH. M. Bisri, Risalah Ahlussunnah wa al-Jama'ah, Kudus: Menara. 1967.

[7] A. Murodi, Keponakan al-Marhum, Wawancara Pribadi, Klender 11 Oktober 2011.

[8] Kelurahan Klender, Laporan Hasil Kegiatan Pembinaan Kelurahan di DKI Jakarta, Jakarta: Kelurahan Klender, Kecamatan Duren Sawit. 2004.

[9] K. R. Zailani et.al., Genealogi Intelektual Ulama Betawi, Melacak Jaringan Ulama Betawi dari Awal Abad 19 Sampai Abad 21, Jakarta: JIC. 2011. 
[10] Wawancara: Hj. Siti Fatimah Hasbiyallah, Istri al-Marhum, Jakarta, 1980 .

[11] Wawancara Pribadi, Hj. Siti Fatimah Hasbiyallah Klender, 11 Oktober 2011.

[12] A. M. Fajar, Reorientasi Pendidikan Islam, Jakarta: Fajar Dunia. 1999.

[13] Y. Fahriyah, Kepala sekolah Madrasah Aliyah az-Ziyadah, Wawancara Pribadi, Klender, 11 Oktober 2011. 